\title{
Primary non-Hodgkin lymphoma of the stomach: endoscopic pattern and prognosis in low versus high grade malignancy in relation to the MALT concept
}

\author{
B G Taal, H Boot, P van Heerde, D de Jong, A A M Hart, J M V Burgers
}

\begin{abstract}
Background-Various histological classifications developed for nodal lymphomas failed to be of value in extranodal lymphomas. More recently, gastric lymphoma is considered to represent a distinctive group derived from mucosa associated lymphoid tissue (MALT).

Aim-To study the prognostic value of malignancy grading based on the concept that most gastric lymphomas are of MALT origin, the endoscopic as well as clinical characteristics in 114 patients with primary gastric non-Hodgkin's lymphoma were evaluated.

Results-In univariate analysis, patients with low grade lymphoma ( $n=51)$ were younger, had less advanced stage, and less frequently bulky disease than those with high grade lymphoma $(n=63)$. In multivariate analysis weight loss and increased erythrocyte sedimentation rate were significantly less frequent in low grade $(45 \%$ and $22 \%)$ compared with high grade lymphoma (75\% and 53\%). In low grade lymphoma endoscopic findings were often interpreted as a benign condition ( 27 of 51 ), in contrast with high grade lymphoma, where carcinoma was most frequently (37 of 63 ) suspected. In low grade lymphoma complete remission rate was $92 \%$, and five year survival $75 \%$. In high grade lymphoma results were significantly less favourable $(p=0.0001)$ : complete remission in $68 \%$, and a five year survival of $46 \%$.
\end{abstract}

Conclusion-Malignancy grading was strongly correlated with treatment outcome; endoscopically low grade lymphoma was often hard to distinguish from benign conditions, whereas high grade lymphoma often revealed carcinoma-like features.

(Gut 1996; 39: 556-561)

Keywords: non-Hodgkin's lymphoma, gastric lymphoma, MALT, prognosis, endoscopy, radiotherapy.

Non-Hodgkin's lymphomas (NHL) are presented with primary extranodal disease in approximately $20-40 \%$ of the cases, most of them are located in the gastrointestinal tract. It is important to differentiate primary gastric NHL from the far more frequent gastric adenocarcinoma because prognosis and therapeutic approaches differ essentially. In primary gastric NHL survival is more favourable because of the natural biological behaviour of the malignancy and the sensitivity to both chemotherapy and radiotherapy. ${ }^{1-3}$

In the past, it has often been difficult to make a histological diagnosis of primary gastric NHL based on endoscopic specimens. The diagnosis of gastric lymphoma can be made on endoscopic samples in up to $93 \%$ of the cases, ${ }^{45}$ in which the use of endoscopic large forceps biopsies can raise the diagnostic yield with sampling of submucosal tissues. The Kiel classification, the most frequently used NHL classification system in Europe, is by definition only applicable to nodal NHL and therefore primary extranodal NHL cannot be classified properly. ${ }^{6}$ Similarly, the prognostic groups of the Working Formulation defining low grade, intermediate grade, and high grade malignancies are based on nodal NHL and cannot be applied directly to primary extranodal NHL. ${ }^{6}$ Primary gastric NHL was first reported by Isaacson and Wright ${ }^{7}$ as a separate entity related to mucosa associated tissue (MALT). The characteristic finding in low grade MALT lymphoma is a diffuse cellar infiltrate of small centrocyte-like cells, which may invade the epithelial lining of glands or crypts forming lymphoepithelial lesions (Fig 1). In high grade lymphoma, the infiltrate consists of large centroblast-like cells and epithelial lesions of MALT origin only occasionally found (Fig 2). This concept was implemented in the recently proposed REAL classification for both nodal and extranodal NHL. ${ }^{8}$ Another new aspect, the

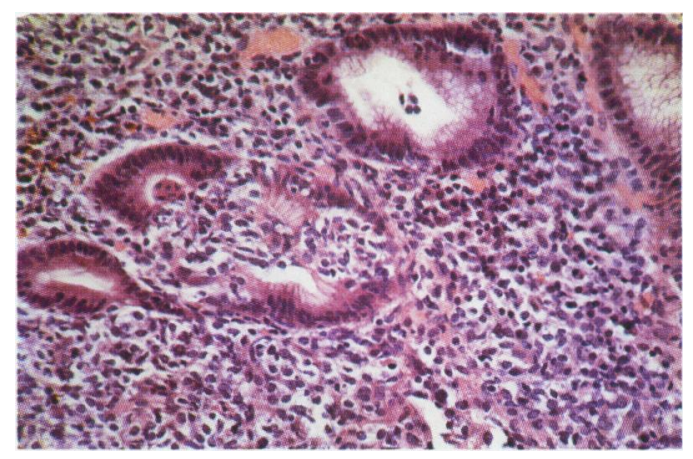

Figure 1: Low grade MALT lymphoma with infiltration of centrocyte-like cells invading the epithelial lining and forming a characteristic lymphoepithelial lesion. 


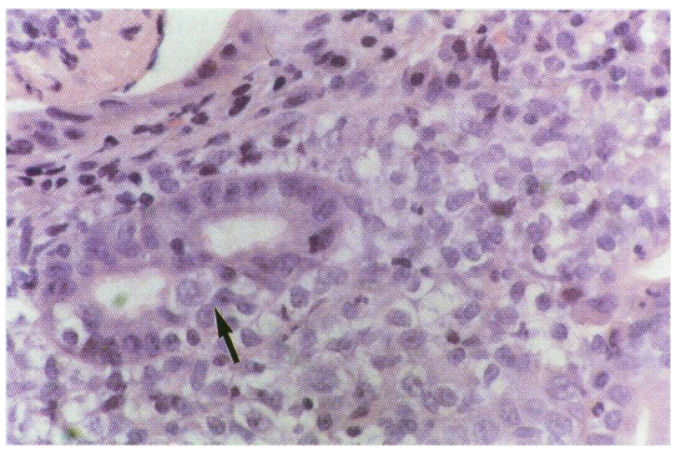

Figure 2: In high grade lymphoma an infiltration consisting of large blastic cells infiltrating the epithelial glands.

role of Helicobacter pylori in the aetiology ${ }^{10}$ and subsequently antibiotic treatment ${ }^{11}$ for a subgroup of patients with limited low grade NHL, is beyond the scope of this paper.

The main object of this study is to evaluate whether subgroup formations of low grade and high grade malignancy taking into account the MALT concept, is useful for interpretation of endoscopic features and to predict clinical outcome.

\section{Methods}

All consecutive patients with localised primary gastric NHL $(n=120)$, treated between 1976 and 1992 in the Netherlands Cancer Institute/ Antoni van Leeuwenhoekhuis of which endoscopic data were available were analysed in this study ( $\mathrm{n}=114)$.

Routine staging procedures included physical examination, inspection of Waldeyer's ring, laboratory tests including haematology and blood chemistry, chest $x$ ray, bone marrow biopsy, lymphangiography, or abdominal computed tomography, or both. Information from laparotomy was included in 33 patients. However, intensive staging procedures at laparotomy with lymphnode sampling were not performed. The extent of the disease was classified according to the modified Ann Arbor system, defining stage I as a process limited to the stomach, stage II as a process with adjacent $\left(\mathrm{II}_{1}\right)$ or regional (para-aortic and para-caval) lymph node involvement $\left(\mathrm{II}_{2}\right)$. Within stage $\mathrm{I}$ and II disease, bulky disease was defined as a tumour mass at palpation, a tumour of more than $10 \mathrm{~cm}$ at endoscopy, or local invasion in neighbouring organs. Patients with stage III and IV disease were excluded because in those cases primary localisation in the stomach often cannot be unequivocally differentiated from extranodal localisation of primary nodal NHL.

The histological diagnosis of primary gastric NHL was mainly made on (repeated) endoscopic biopsy specimens $(n=109)$ and only occasionally on gastrectomy specimens $(n=5)$. Our recommended standard procedure was to take at least 10 biopsy specimens per patient. The slides were reviewed by two experienced haematopathologists $(\mathrm{PvH}$ and DdJ). All cases were classified as low grade or high grade lymphoma based on the MALT concept. In low grade malignancy diffuse infiltration consisted of small centrocyte-like cells with invasion of the epithelial lining of glands and crypts, forming the characteristic lymphoepithelial lesion. In high grade malignancy the infiltrate dominated by large blastic cells of B-cell phenotype. Lymphoepithelial lesions cannot be recognised in all cases of high grade primary gastric lymphoma. ${ }^{7}$ A MALT origin was defined on basis of a distinct lymphoepithelial lesion or the clinical presentation of a mono-localisation in the stomach with no history of nodal lymphadenopathy, or both. The endoscopic patterns were assessed for the following characteristics: large ulceration, multiple small ulcerations, diffuse infiltration, and a polypoid mass as described previously. ${ }^{12}$ Initial endoscopic diagnoses were evaluated. Treatment schedules were based on stomach conserving therapy as advocated earlier. ${ }^{2}{ }^{13}$ The preferred treatment consisted of radiotherapy (20 Gy on the whole abdomen and a booster dose of $20 \mathrm{~Gy}$ on the gastric region) in stage $\mathrm{I}$ and $\mathrm{II}_{1}$ disease and combination chemotherapy regimen (usually including cyclophosphamide, adriamycin, vincristine or teniposide, and prednisone) with adjuvant radiotherapy in stage $\mathrm{II}_{2}$ disease and in cases of bulky disease. Several patients $(n=23)$ were treated otherwise, usually with limited radiotherapy, for patient related factors, such as poor condition and old age. Evaluation, including endoscopic examination, was performed two months after completing treatment and yearly during follow up. Response was assessed according to the WHO criteria: a complete response defined as no macroscopic tumour, histologically confirmed; a partial remission when at least $50 \%$ tumour reduction was found; no change in case of variation within either $50 \%$ decrease or $25 \%$ increase, and progressive disease when an increase of at least $25 \%$ was present. Median follow up was 70 months with a range from six to 173 months. Overall survival and disease free survival were calculated according to KaplanMeyer.

\section{Results}

Applying the MALT concept, malignancy was classified as low grade $(n=51$ or $45 \%)$ or high grade ( $n=63$ or $55 \%$ ) lymphoma. In high grade lymphoma the MALT origin was recognised by the characteristic lymphoepithelial lesion in a subgroup of 16 patients. Table I lists the characteristics of the patients. Among the 114 patients studied, 63 were men and 51 women with a median age of 64 years. Most $(n=82$ or $72 \%$ ) patients were in stage I. Staging procedures were similar in both low and high grade lymphomas. As we advocated a stomach conserving therapy, data from laparotomy were available only in a subgroup of patients $(n=33)$, and not significantly different divided over the two histological categories: 12 in low grade $(25 \%)$ and 21 in high grade lymphoma (33\%). It should be noted that perigastric lymph nodes in stage $\mathrm{II}_{1}$ are difficult to visualise with clinical staging only and potentially cause an underestimate of stage $\mathrm{II}_{1}$ disease in our study group. Endoscopic ultrasonography was used 
TABLE I Patient characteristics in primary non-Hodgkin's lymphoma of the stomach according to the grade of malignancy in relation to the $M A L T$ concept

\begin{tabular}{|c|c|c|c|c|c|}
\hline & \multirow{2}{*}{$\begin{array}{l}\text { Low grade } \\
(n=51)\end{array}$} & \multirow{2}{*}{$\begin{array}{l}\text { High grade } \\
(n=63)\end{array}$} & \multicolumn{2}{|l|}{$P$ Value } & \multirow{2}{*}{$\begin{array}{l}\text { Total } \\
(n=114)\end{array}$} \\
\hline & & & Overall & Corrected $^{\star}$ & \\
\hline $\begin{array}{l}\text { General: } \\
\text { Age (y), median (range) } \\
\text { Sex, male/female } \\
\text { Stage I } \\
\text { Stage } \mathrm{II}_{1} \\
\text { Stage } \mathrm{II}_{2} \\
\text { Bulky disease }\end{array}$ & $\begin{array}{l}57(27-84) \\
26 / 25 \\
42(82) \\
5(10) \\
4(8) \\
8(16)\end{array}$ & $\left.\begin{array}{l}67(18-89) \\
37 / 26 \\
40(63) \\
13(21) \\
10(16) \\
23(37)\end{array}\right)$ & $\begin{array}{l}0.019 \dagger \\
0.41 \ddagger \\
0.042 \S \\
0.013 \ddagger\end{array}$ & $\begin{array}{l}0 \cdot 18 \\
1 \cdot 00 \\
0 \cdot 38 \\
0 \cdot 12\end{array}$ & $\begin{array}{l}64(18-89) \\
63 / 51 \\
82 \\
18 \\
14 \\
31\end{array}$ \\
\hline $\begin{array}{l}\text { Presenting symptoms: } \\
\text { Epigastric pain } \\
\text { Abdominal fullness } \\
\text { Vomiting } \\
\text { Weight loss } \\
\text { Fever } \\
\text { Blood loss: acute } \\
\text { Blood loss: chronic } \\
\text { Duration (months): median (range) }\end{array}$ & $\begin{array}{l}30(59) \\
16(30) \\
10(20) \\
23(45) \\
2(4) \\
10(20) \\
5(10) \\
3(0-120)\end{array}$ & $\left.\begin{array}{l}53(84) \\
26(41) \\
20(32) \\
47(75) \\
2(3) \\
9(14) \\
8(13) \\
4(1-24)\end{array}\right\}$ & $\begin{array}{l}0 \cdot 034 \ddagger \\
0 \cdot 074 \ddagger \\
0 \cdot 18 \ddagger \\
0 \cdot 003 \ddagger \\
0 \cdot 80 \ddagger \\
0 \cdot 71 \ddagger \\
1 \cdot 00 \dagger\end{array}$ & $\begin{array}{l}0 \cdot 31 \\
0 \cdot 52 \\
0 \cdot 96 \\
0 \cdot 045 \\
1 \cdot 00 \\
1 \cdot 00 \\
1 \cdot 00\end{array}$ & $\begin{array}{r}83 \\
42 \\
30 \\
70 \\
4 \\
19 \\
13 \\
4(1-120)\end{array}$ \\
\hline $\begin{array}{l}\text { Physical examination: } \\
\text { WHO performance } 1 \\
2 \\
3 \\
4 \\
\text { unknown } \\
\text { Abdominal mass }\end{array}$ & $\begin{array}{c}18(35) \\
28(55) \\
3(6) \\
0(0) \\
2(4) \\
3(6)\end{array}$ & $\begin{array}{c}12(19) \\
38(60) \\
10(16) \\
0(0) \\
3(5) \\
11(17)\end{array}$ & $\begin{array}{l}0.020 \$ \\
0.0869\end{array}$ & $\begin{array}{l}0 \cdot 18 \\
0 \cdot 61\end{array}$ & $\begin{array}{r}30 \\
66 \\
13 \\
0 \\
5 \\
14\end{array}$ \\
\hline $\begin{array}{l}\text { Laboratory findings: } \\
\mathrm{Hb} \leqslant 6 \cdot 5 \mathrm{mmol} / 1 \\
\mathrm{ESR} \geqslant 30 \mathrm{~mm} / 1 \mathrm{st} \mathrm{hr} \\
\mathrm{LDH} \geqslant 330 \mathrm{U} / 1 \text { (upper limit) }\end{array}$ & $\begin{array}{c}6(12) \\
11(22) \\
0(0)\end{array}$ & $\begin{array}{c}10(16) \\
34(53) \\
4(6)\end{array}$ & $\begin{array}{c}0.66 \ddagger \\
<0.001 \ddagger \\
0.139\end{array}$ & $\begin{array}{l}0.61 \\
0.0088 \\
0.78\end{array}$ & $\begin{array}{r}16 \\
45 \\
4\end{array}$ \\
\hline
\end{tabular}

*Correction of the $\mathrm{p}$ value according to Hommel's procedure. $†$ Mann-Whitney test, $\ddagger \chi^{2}$ test, Mantel-Haenszel trend test, ๆFisher's exact test. $\mathrm{Hb}=$ haemoglobin, ESR=erythrocyte sedimentation rate, $\mathrm{LDH}=$ lactodehydrogenase.

sedimentation rate, $\mathrm{LDH}=$ lactodehydrogenase.
Figures in parentheses are percentages unless otherwise stated.

infrequently, especially in the early years of the study period, and is therefore not incorporated in the staging evaluation of this study. In the high grade NHL group twice as many patients were considered to have stage II (36\% v $18 \%)$. The same was true for bulky disease $(37 \%$ in high grade $v 16 \%$ in the low grade group). However, initial statistical differences for stage and bulky disease in low and high grade lymphoma failed to reach significance, when corrected for multiple parameters analysis.

Presenting symptoms were non-specific, such as epigastric pain, anorexia, and vomiting. Only weight loss occurred significantly more often in the high grade group (75\% $v 45 \%)$. Duration of symptoms was similar in both

TABLE II Endoscopic findings in primary non-Hodgkin's lymphoma of the stomach according to the grade of malignancy related to the MALT concept

\begin{tabular}{|c|c|c|c|c|}
\hline & $\begin{array}{l}\text { Low grade } \\
\text { malignancy } \\
(n=51)\end{array}$ & $\begin{array}{l}\text { High grade } \\
\text { malignancy } \\
(n=63)\end{array}$ & $p$ Value & $\begin{array}{l}\text { Total } \\
(n=114)\end{array}$ \\
\hline $\begin{array}{l}\text { Main patterns: } \\
\text { Ulceration: }\end{array}$ & & & & \\
\hline $\begin{array}{l}\text { large } \\
\text { multiple, small } \\
\text { Diffuse infiltration } \\
\text { Polypoid mass } \\
\text { Not classified }\end{array}$ & $\begin{array}{l}17(31) \\
10(20) \\
9(18) \\
13(25) \\
2(4)\end{array}$ & $\begin{aligned} 22(35) \\
7(11) \\
9(14) \\
21(33) \\
4(6)\end{aligned}$ & $0.69^{\star}$ & $\begin{array}{r}38 \\
17 \\
18 \\
34 \\
7\end{array}$ \\
\hline $\begin{array}{l}\text { Endoscopic diagnosis: } \\
\text { Malignancy: } \\
\text { NHL } \\
\text { Carcinoma } \\
\text { NHL or carcinoma } \\
\text { Benign condition: } \\
\text { Benign ulcer } \\
\text { Gastritis, erosions } \\
\text { Other }\end{array}$ & $\begin{aligned} 24(47) \\
9(18) \\
13(25) \\
2(4) \\
27(52) \\
17(33) \\
4(8) \\
6(12)\end{aligned}$ & $\begin{array}{r}45(71) \\
8(13) \\
25(40) \\
12(19) \\
28(28) \\
10(16) \\
0(0) \\
8(13)\end{array}$ & $0 \cdot 008^{\star}$ & $\begin{array}{r}69 \\
17 \\
38 \\
14 \\
45 \\
27 \\
4 \\
14\end{array}$ \\
\hline $\begin{array}{l}\text { Histological diagnosis: } \\
\text { NHL on first biopsies } \\
\text { NHL on repeated biopsies } \\
\text { Carcinoma, later NHL } \\
\text { NHL on resection material }\end{array}$ & $\begin{array}{c}38(75) \\
11(22) \\
0(0) \\
2(4)\end{array}$ & $\begin{array}{c}50(79) \\
5(8) \\
5(8) \\
3(5)\end{array}$ & $0.040 \dagger$ & $\begin{array}{r}88 \\
16 \\
5 \\
5\end{array}$ \\
\hline
\end{tabular}

$\star=\chi^{2}$ test, + Fisher's exact test. Figures in parentheses are percentages. groups with a median of four months. Blood loss at presentation, either acute $(16 \%)$ with melaena and haematemesis, or chronic with anaemia (11\%) was equally present in both NHL groups. General condition, measured as WHO performance status, tended to be better in low grade lymphoma. Abnormalities in laboratory tests were usually not specific, although the erythrocyte sedimentation rate was significantly more often raised in high grade lymphoma. Serum lactodehydrogenase, considered a prognostic marker in nodal NHL, was found not to be increased in both low grade $(0 \%)$ and only occasionally raised in high grade lymphoma (4\%).

At endoscopy (Table II) three main patterns ${ }^{13}{ }^{14}$ could be recognised: ulceration (48\%), diffuse infiltration (16\%), and a polypoid mass $(30 \%)$. These features were equally found in low and high grade lymphoma. In the ulcerative type large superficial ulcers with long stellated branches were most characteristic for NHL, but more penetrating ulcers were also found; these various ulcers can be difficult to differentiate from benign as well as from carcinomatous ulcers (Fig 3). Small ulcers and erosions (Fig 4) can be indistinguishable from benign peptic ulcer or gastritis, or both. The diffuse infiltrative endoscopic pattern with large nodular, sometimes giant folds (Fig 5) can also be seen in carcinoma of the linitis plastica type, metastases in the gastric wall as seen in the lobular type of breast cancer, ${ }^{15}$ and in benign conditions as Menetrier's disease and gastric syphilis. Polypoid masses (Fig 6) varied in size, and were sometimes comparatively small, and difficult to find.

To arrive at a correct endoscopic diagnosis proved extremely difficult: in only 17 of all cases $(15 \%)$ NHL was endoscopically suspected; more often carcinoma was expected $(n=38$ or $33 \%)$. Also in 45 patients $(39 \%)$ a benign condition was diagnosed. Significant differences were present in interpretation of endoscopic findings in low and high grade lymphoma. In half of the patients with low

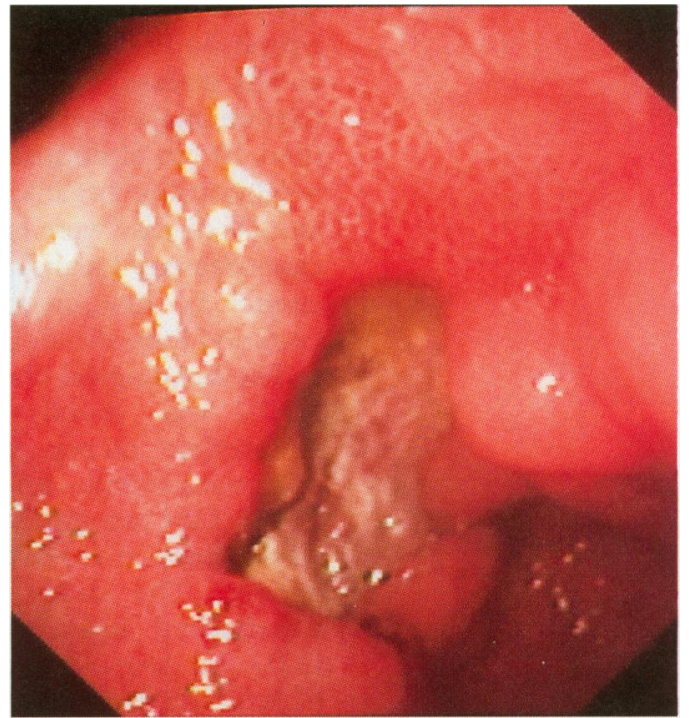

Figure 3: A large, sharply demarcated ulcer in NHL, which might be indistinguishable from carcinoma. 


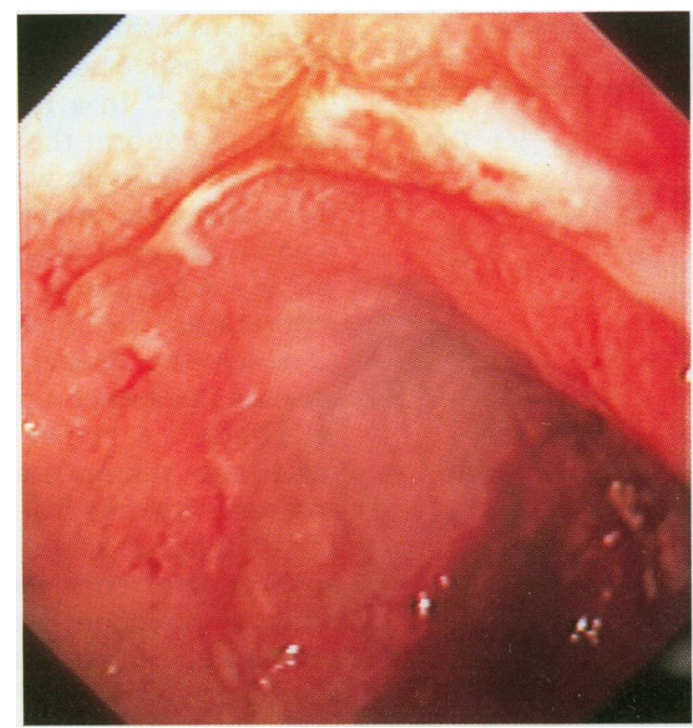

Figure 4: Small, multiple erosions in NHL, which may be interpreted as benign gastritis.

grade lymphoma $(n=27)$ a benign condition was diagnosed, as it frequently (33\%) gave the impression of a benign ulcer. However, in high grade lymphoma findings were mainly interpreted as malignancy ( $\mathrm{n}=45$ or $71 \%$ ), and differentiation from carcinoma was difficult.

A correct histological diagnosis after the first endoscopy was made in $75 \%$ of the low grade and $79 \%$ of the high grade cases (Table II). In low grade lymphoma, however, repeated endoscopy with biopsies, was more frequently needed in $22 \%$ versus $8 \%$ in high grade giving a diagnosis of $\mathrm{NHL}$ in $97-87 \%$. Initial misdiagnosis of adenocarcinoma instead of lymphoma was only a problem in the high grade group ( $8 \%$ ) in the early years of the study (four cases in 1977-79 and in 1 in 1987), before immunological staining procedures were routinely applied in poorly differentiated gastric tumours.

Treatment (Table III) consisted of radiotherapy in most of the patients, $88 \%$

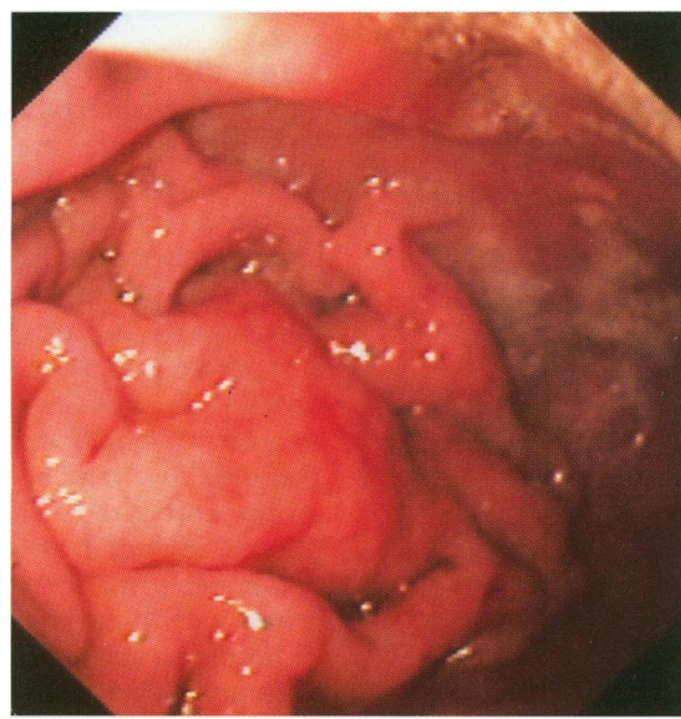

Figure 5: The diffuse type of NHL with thickened, nodular, sometimes giant folds, sometimes difficult to differentiate from linitis plastica.

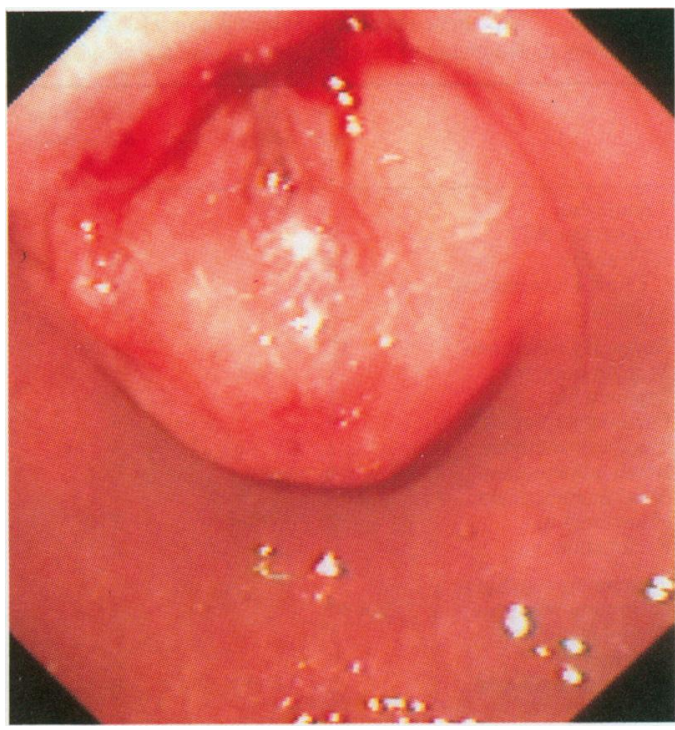

Figure 6: A small polypoid mass obstructing the pylorus due to $N H L$.

$(n=45)$ in low grade and $73 \%(n=46)$ in the high grade NHL group, in some cases combined with resection or chemotherapy, or both. Resection was possible in 10 of 12 patients who underwent surgery and proved to be incomplete at microscopy in four cases in the low malignancy group; in the high grade group data were comparable (Table III). Overall tumour response was excellent in both groups with $79 \%(n=90)$ complete remissions. The recurrence rate was lower in the low grade group $(12 \%)$ compared with the high grade group $(20 \%)$, but not significantly different. Although Waldeyer's ring might strongly be related to the MALT tissue in the stomach, recurrences in that particular region did occur at only one occasion.

In low grade NHL overall survival at five year was $75 \%$ and significantly $(p=0.0001)$ better compared with high grade $(46 \%)$ (Fig 7). The same was true for disease free survival with $70 \%$ and $38 \%$ respectively. Based on stage (Fig 8), overall five year survival was $65 \%$ for stage I and $44 \%$ for stage II $(\mathrm{p}=0.0011)$.

\section{Discussion}

To establish an endoscopic diagnosis of primary gastric lymphoma is often difficult. Because of the various macroscopic patterns the endoscopic diagnosis at first sight may range from benign gastritis to carcinoma. Although large stellated ulcers are characteristic for NHL, ${ }^{16}$ several other types of ulcers in NHL may be indistinguishable from benign peptic ulcers or when small, superficial and multiple, benign gastritis with erosions. ${ }^{14} \mathrm{~A}$ polypoid mass is often difficult to differentiate from gastric carcinoma; the same applies to diffuse infiltration of the mucosa and submucosa by NHL and the linitis plastica type of gastric carcinoma or diffuse metastatic disease in lobular breast cancer. ${ }^{15}$ In this study, low grade lymphoma was frequently interpreted as a benign ulcer, while most high grade lympho- 
TABLE III Treatment results in primary non-Hodgkin's lymphoma of the stomach according to the grade of malignancy related to the $M A L T$ concept

\begin{tabular}{|c|c|c|c|c|}
\hline & $\begin{array}{l}\text { Low grade } \\
\text { malignancy } \\
(n=51)\end{array}$ & $\begin{array}{l}\text { High grade } \\
\text { malignancy } \\
(n=63)\end{array}$ & p Value & $\begin{array}{l}\text { Total } \\
(n=114)\end{array}$ \\
\hline $\begin{array}{l}\text { Treatment: } \\
\text { Resection }+\mathrm{RT}^{\star} \\
\mathrm{RT}^{\star} \text { alone } \\
\mathrm{CT}+\mathrm{RT} \pm \text { resection } \\
\text { Various }\end{array}$ & $\begin{array}{r}6 \\
32 \\
7 \\
6\end{array}$ & $\begin{array}{r}11 \\
27 \\
8 \\
17\end{array}$ & $0 \cdot 17 \ddagger$ & $\begin{array}{l}19 \\
58 \\
14 \\
23\end{array}$ \\
\hline $\begin{array}{l}\text { Surgical procedures: } \\
\text { Staging only } \\
\text { Irresectable } \\
\text { Partial gastrectomy } \\
\text { Total gastrectomy } \\
\text { Irradical resection } \\
\text { Specific indications: } \\
\text { Haemorrhage } \\
\text { Perforation }\end{array}$ & $\begin{array}{r}12 \\
1 \\
1 \\
9 \\
1 \\
4 \\
\\
2 \\
0\end{array}$ & $\begin{array}{r}21 \\
5 \\
3 \\
9 \\
4 \\
0 \\
2 \\
2 \\
2\end{array}$ & & $\begin{array}{r}33 \\
6 \\
4 \\
18 \\
5 \\
4 \\
\\
4 \\
2\end{array}$ \\
\hline $\begin{array}{l}\text { Treatment results: } \\
\text { Complete response } \\
\text { Partial remission } \\
\text { No change } \\
\text { Progressive disease } \\
\text { Unknown }\end{array}$ & $\begin{array}{r}47 \\
1 \\
0 \\
2 \\
1\end{array}$ & $\begin{array}{r}43 \\
7 \\
2 \\
9 \\
2\end{array}$ & $0.007 \S$ & $\begin{array}{r}90 \\
8 \\
2 \\
11 \\
3\end{array}$ \\
\hline $\begin{array}{l}\text { Recurrence: } \\
\text { Stomach } \\
\text { Lymph nodes } \\
\text { Waldeyer's ring } \\
\text { Pleura, lung } \\
\text { Other }\end{array}$ & $\begin{array}{l}2 \\
1 \\
1 \\
0 \\
2\end{array}$ & $\begin{array}{l}4 \\
9 \\
0 \\
4 \\
2\end{array}$ & $0 \cdot 129$ & $\begin{array}{r}6 \\
10 \\
1 \\
4 \\
4\end{array}$ \\
\hline
\end{tabular}

${ }^{\star}$ RT = Radiotherapy: $20 \mathrm{~Gy}$ on the whole abdomen and $20 \mathrm{~Gy}$ as a booster dose to the stomach. $+\mathrm{CT}=$ Chemotherapy schedules, usually containing cyclophosphamide, adriamycin, vincristine

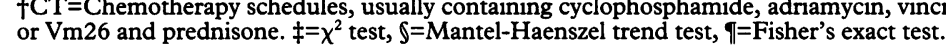

mas were scored as carcinoma. An accurate histological diagnosis on biopsy samples could be made in $77 \%$ at first endoscopy and up to $91 \%$ with repeated endoscopy. Histological confirmation of low grade lymphoma required more often repeated endoscopy plus biopsies, although in several patients the characteristic centro-cytic infiltrate and lymphoepithelial invasion could be found in previous biopsy

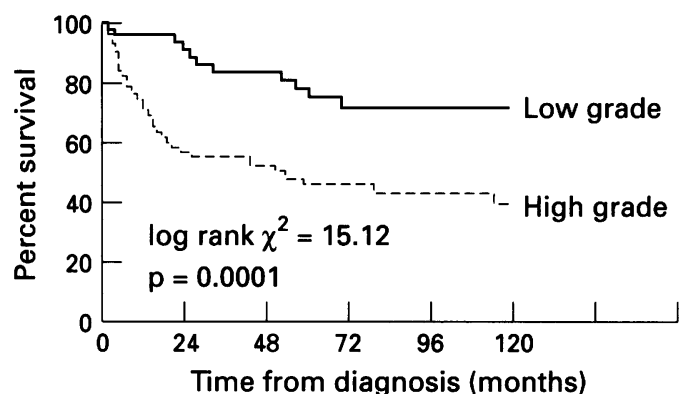

Figure 7: Overall survival in primary non-Hodgkin's lymphoma of the stomach: low grade and high grade malignancy related to the $M A L T$ concept, at five years $75 \%$ and $46 \%$ respectively $(p=0.0001)$.

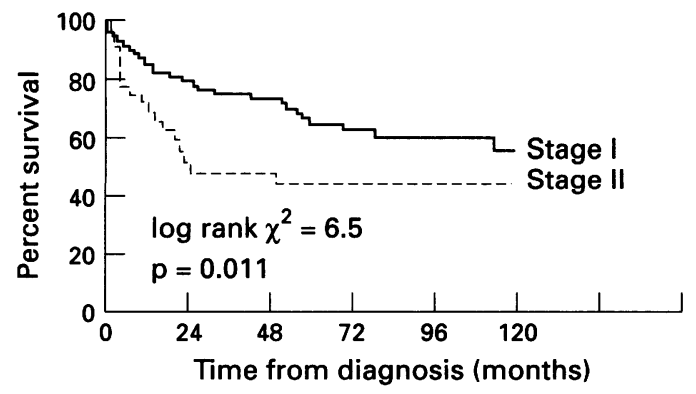

Figure 8: Overall survival in primary non-Hodgkin's lymphoma of the stomach, according to stage: in stage I at five years $65 \%$ compared with $44 \%$ in stage II $(p=0.0011)$. specimens retrospectively. In published studies the diagnostic success rate varies from $44 \%{ }^{16}$ up to $96 \% .{ }^{14}$ In a recent German series ${ }^{4}$ the ability to confirm the endoscopic diagnosis of NHL with biopsies was shown to be related to the endoscopic appearance: in the exophytic type an accurate diagnosis was made in $77 \%$ and in the infiltrative type in only $32 \%$. Several reports stress the impact of large biopsy forceps to reach the deeper tissues, because NHL arises in the deeper mucosal layer. As described by Hintze ${ }^{17}$ a biopsy forceps of $5 \mathrm{~mm}$ may reach the submucosa in $53 \%$ of cases, in contrast with only $5 \%$ using a $3.5 \mathrm{~mm}$ forceps. In a Japanese series of eight patients ${ }^{18}$ the application of a new technique, the endoscopic mucosal resection, was reported to be very promising, as it provided tissue biopsy specimens of $1 \cdot 0-2.5 \mathrm{~cm}$. The well known large snare biopsy may also prove to be of value, as reported previously; brush cytology does not provide much additional benefit. ${ }^{19}$ Other methods to improve the diagnostic yield of endoscopic biopsy specimens is the use of immunohistochemical techniques ${ }^{20}$ as well as polymerase chain reaction assays to detect monoclonal B-cell populations. ${ }^{21}$ Since the introduction of these techniques, problems in the differential diagnosis in some patients with high grade NHL, in whom initially a histological diagnosis of adenocarcinoma was made, have largely been solved.

Although the primary histological diagnosis may be difficult to obtain, once the diagnosis has been confirmed, Seifert ${ }^{4}$ reported that the malignancy grading of lymphoma based on endoscopic biopsy specimens did not differ from that based on resection material. We consider these findings of utmost importance as a stomach conserving approach is advocated increasingly. ${ }^{13}$ Only two other series ${ }^{22}{ }^{23}$ deal with the relation of the MALT concept and prognosis. They are, however, based on resection material and described from the pathologist's point of view with limited information on symptoms, signs, and therapy schedules. They emphasise the importance of malignancy grading, depth of infiltration, and stage.

In this study, we analysed different endoscopic patterns and prognosis in low grade and high grade malignancy related to the MALT concept. The characteristic lymphoepithelial lesion, as seen in the low grade malignancy group, is less frequently seen in the high grade group $(n=16)$. In view of the small numbers we did not analyse these patients as a separate subgroup. Moreover, such a subdivision did not have impact on the choice of treatment, which currently is chemotherapy. Features that may be typical for the low grade group compared with the high grade lymphoma, included: younger age, early stage, and better performance status. In contrast, in the group with high grade NHL, patients tended to be older, and to have more advanced stage and more often bulky disease, but apart from weight loss they presented with similar nonspecific complaints as the patients with lowgrade MALT lymphoma. If we take into 
account the fact that we tested 16 variables (Hommel's procedure), only for raised erythrocyte sedimentation rate and weight loss the collected $p$ value remained significant. For the other parameters evidence is less convincing, and for them confirmation is still needed.

In this study treatment results were fairly good overall, but significantly better in low grade lymphomas: complete remissions, recurrence rate, disease free survival, and overall survival compared favourably with the high grade group. Local recurrences in the stomach were an uncommon event in both groups (4-6\%), which is a stimulant for continuing a stomach conserving approach.

Recently, treatment of low grade gastric lymphoma by eradication of $H$ pylor $i$ with dual or triple therapy including antibiotics and a proton pump inhibitor seems very promising ${ }^{11}$ as first described by Wotherspoon in $1993 .{ }^{24} \mathrm{At}$ present, results of two series are available: a German series of 33 patients ${ }^{11}$ with low grade MALT lymphoma, in which a combination of omeprazole and amoxycillin resulted in $70 \%$ complete and $12 \%$ partial regression; the second series from Switzerland reported similar results in 26 cases. ${ }^{25}$ It is hypothesised that in low grade lymphoma, eradication of $H$ pylori may abolish an antigenic drive of B-cell proliferation and therefore lead to regression of lymphoma. In high grade lymphoma the proliferative process is most probably fully autonomous and no longer dependent on antigenic drive. Nevertheless, regression has been reported in some patients with high grade gastric lymphoma. ${ }^{26}$ Although longterm results are awaited, the simple and appealing approach of $H$ pylori eradication would have been a treatment option in a small subgroup of our patient population, which we have treated up till now with radiotherapy only.

In this study, we have shown that, although no specific endoscopic pattern can be identified for gastric NHL, a tendency to more resemblance with benign ulcer in low grade MALT and a carcinoma-like appearance in the high grade lymphomas exists. As malignancy grade, related to the MALT concept, is highly related to treatment response and survival and thus prognosis, accurate diagnosis remains of utmost significance, which can be achieved by a high index of suspicion and multiple large endoscopic biopsy specimens. In view of multiple therapeutic options and its good prognosis, differentiation of gastric lymphoma from other gastric malignancies is of great value.

We are gratefully indebted to Mrs E Brugman for careful preparation of the manuscript.

1 Maor MH, Velasquez WS, Fuller LM, Silvermintz KB. Stomach conservation in stages IE and IIE gastric nonHodgkin's lymphoma. $\mathcal{f}$ Clin Oncol 1990; 8: 266-71.
2 Burgers JMV, Taal BG, van Heerde P, Somers R, den Hartog Jager FCA, Hart AAM. Treatment results of primary stage I and II non-Hodgkin's lymphoma of the stomach. Radiother Oncol 1988; 11: 319-26.

3 Taal BG, Burgers JMV, van Heerde P, Hart AAM, Somers R. The clinical spectrum and treatment of primary non-Hodgkin's lymphoma of the stomach. Ann primary non-Hodgkin's

4 Seifert E, Schulte F, Weismuller J, de Mas CR, Stolte M. Endoscopic and bioptic diagnosis of malignant nonHodgkin's lymphoma of the stomach. Endoscopy 1993; 25: 497-501.

5 Caletti G, Barbara L. Gastric lymphoma: difficult to diagnose, difficult to stage? Endoscopy 1993; 25: 528-30.

6 Rohatiner A, d'Amore F, Coiffier B, Crowther D, Gospodarpwicz M, Isaacson $\mathrm{P}$, et al. Report on a workshop convened to discuss the pathological and staging classifications of gastrointestinal tract lymphoma. Ann Oncol 1994; 5: 397-400.

7 Isaacson PG, Wright DH. Malignant lymphoma of mucosaassociated lymphoid tissue. A distinctive type of B-cell lymphoma. Cancer 1983; 52: 1410-6.

8 Harris NL, Jaffe ES, Stein H, Banks PM, Chan JKC, Cleary $M L$, et al. A revised European-American classification of lymphoid neoplasms: a proposal from the International Lymphoma Study Group. Blood 1994; 84: 1361-92.

9 Wotherspoon AC, Ortiz-Hidalga C, Falzon MR, Isaacson PG. Helicobacter associated gastritis and primary B-cell gastric lymphoma. Lancet 1991; ii: 1175-6.

10 Parsonnet J, Hansen S, Rodriquez L, Gelb AB, Warnke RA, Jellum E, et al. Helicobacter pylori infection and gastric lymphoma. N Engl f Med 1994; 330: 1267-71.

11 Bayerdörffer E, Neubaeur A, Rudolph B, Thiede C, Lehn N, Eidt S, et al. Regression of primary gastric lymphoma of mucosa-associated lymphoid tissue type lymphoma of mucosa-associated lymphoid tissue type after cure of

12 Taal BG, den Hartog Jager FCA, Tytgat GNJ. The endoscopic spectrum of primary non-Hodgkin's lymphoma of the stomach. Endoscopy 1987; 19: 190-2.

13 Taal BG, den Hartog Jager FCA, Burgers JMV, van Heerde P, Tio TL. Primary non-Hodgkin's lymphoma of the stomach: changing aspects and therapeutic choices. Eur $\mathcal{F}$ Cancer Clin Oncol 1989; 25: 439-50.

14 Spinelli P, Lo Gullo C, Pizzetti P. Endoscopic diagnosis of gastric lymphomas. Endoscopy 1980; 12: 211-4.

15 Taal BG, den Hartog Jager FCA, Steinmetz R, Peterse H. The spectrum of gastrointestinal metastases of breast carcinoma: I. Stomach. Gastrointest Endosc 1992; 38: 130-5.

16 Fork FTh, Haglund U, Hogstrom H, Wehlin L. Primary gastric lymphoma versus gastric cancer: an endoscopic and radiographic study of differential diagnostic possibilities. Endoscopy 1985; 17: 5-7.

17 Hintze RE. Endoskopische diagnostik der gastrointestinalen Lymphome. Verdauungskrankheiten 1989; 7: 18-24.

18 Suekane $H$, Iida $M$, Kuwano $Y$, Kohrogi $N$, Yao $T$, Iwashita A, et al. Diagnosis of primary early gastric lymphoma: usefulness of endoscopic mucosal resection for histologic evaluation. Cancer 1993; 71: 1207-13.

19 Nelson RS, Lanza FL. The endoscopic diagnosis of gastric lymphoma: gross characteristics and histology. Gastrointest Endosc 1974; 21: 66-8.

20 Arista-Nasr J, Jimenez A, Keirns C, Larraza O, LarrivaSahd J. The role of the endoscopic biopsy in the diagnosis of gastric lymphoma: a morphologic and immunohistochemical reappraisal. Hum Pathol 1991; 22: 339-48.

21 Algara P, Martinez P, Sanchez L, Villuendas R, Benitez J, Rivas C, et al. The detection of B-cell monoclonal populations by polymerase chain reaction: accuracy of approach and application in gastric endoscopic biopsy specimens. Hum Pathol 1993; 24: 1184-8.

22 Cogliatti SB, Schmid U, Schumacker U, Eckert U, Harsmann ML, Hedderick J, et al. Primary B-cell gastric lymphoma: a clinicopathological study of 145 patients. Gastroenterology 1991; 101: 1159-70.

23 Gastroenterology 1991; 101: 1159-70. $\mathrm{P}$ Gastrointestinal malignant lymphomas of the mucosa associated lymphoid tissue lymphoma: factors relevant to prognosis. Gastroenterology 1992; 102: 1628-38

24 Wotherspoon AC, Ortiz-Hiddgo C, Falzon MR, Isaacson PG. Helicobacter pylori associated gastritis and primary B-cell gastric lymphoma. Lancet 1991; 338: 1175-6.

25 Roggero E, Zucca E, Pinotti G, Pascarella A, Capella C, Savio A, Pedrinis E, Paterlini A, Venco A, Cavalli F. Eradication of Helicobacter pylori infection in primary lowgrade gastric lymphoma of mucosa-associated lymphoid tissue. Ann Intern Med 1995; 122: 767-9.

26 Weber DM, Dimophoulos MA, Anandu DP, Pugh WC, Steinbach G. Regression of gastric lymphoma of mucosa Steinbach G. Regression of gastric lymphoma of mucosa Helicobacter pylori. Gastroenterology 1994; 107: 1835-8.

27 Boot H, de Jong d, van Heerde P, Taal BG. Role of Helicobacter pylori eradication in high grade MALT lymphoma. Lancet 1995; 346: 448-9. 